\title{
The impact of season, parity and breed on selected reproductive performance parameters of sows
}

\author{
D. Knecht, S. Środoń, and K. Duziński \\ Institute of Animal Breeding, Wroclaw University of Environmental and Life Sciences, Chelmonskiego 38C, \\ 51-630 Wroclaw, Poland \\ Correspondence to: S. Środoń (sebastian.srodon@up.wroc.pl)
}

Received: 11 February 2014 - Accepted: 13 November 2014 - Published: 4 March 2015

\begin{abstract}
The aim of the study was to identify the detailed impact of the season, parity and breed on reproductive performance of sows. The experimental material consisted of 2100 sows, in 3 breed variants: 700 PL, 700 PLW, 700 crossbreeds PL $\times$ PLW. Sows were observed until parity 5 . In the context of the breed, depending on the order of parity groups of 140 sows were isolated. Then, sows were divided in terms of farrowing season into subgroups numbering 35 sows. At the age of 8 months gilts were allocated for reproduction performance. The highest seasonal impact was noted for piglet birth weight $(P \leq 0.01)$. Parity had less effect only on the number of piglets weaned $(P \leq 0.05)$. Breed influenced to a lesser extent the number of piglets born live and weaned $(P \leq 0.05)$, while birth and weaning weight had greater importance for piglets $(P \leq 0.01)$. The interaction between the studied factors was also observed. The impact of season, parity and breed interdependence on the number of piglets born live were confirmed statistically $(P \leq 0.05)$. The analysis of piglet birth weight allowed the stronger interaction effect of parity $\times$ breed on this parameter to be noted $(P \leq 0.01)$. The analysis of variance for piglet weaning weight confirmed strong relations between all tested factors $(P \leq 0.01)$. Our study has shown that reproductive parameters can be strongly affected by season and parity. In addition, it must be emphasized that the impact of these factors was different for the studied breeds of sows.
\end{abstract}

\section{Introduction}

Improving the efficiency of piglet production is only possible through detailed analysis of all factors. It is estimated that over the course of their whole lives sows rear an average of only 30-40 piglets (Patterson et al., 2010), thus the validity of a careful evaluation of the reproductive performance of sow determinants.

Among the most frequently mentioned factors affecting the reproductive performance of sows should be highlighted: season, parity, breed, lactation length and nutrition (Bloemhof et al., 2008). The last two factors can be easily eliminated or at least standardized using identical/similar levels of nutrition and lactation length. The season, parity and also breed directly affect the volume of production, therefore it is important to perform a detailed analysis of the impact of these factors.
Season is an issue which is one of the most important environmental factors directly affecting the reproductive performance of pigs (Love et al., 1993). It has been proved that season has a direct impact on litter size and piglet survival after birth (Tummaruk et al., 2010). Additionally, it may affect results in the rearing of piglets, for example due to heat stress and feed intake during lactation. Within the season, temperature variation and photoperiodic reaction are considered the main causes influencing fertility (Knecht et al., 2013), although the resistance of individuals is dependent on the breed (Wysokońska and Kondracki, 2013).

Parity order is associated with physiology, primarily with growth of the organism, and in particular with the development of the reproductive system. Lengthening the production life of sows should be an important foundation of production because from the 3rd parity sows generate financial profitability in terms of their exploitation (Engblom et al., 2007). It should be noted that the results of research into 
parity are not clear. Takai and Koketsu (2008) observed that thanks to repeated insemination of sows higher numbers of piglets were born only in the 1st and 2nd parity, but not in subsequent ones. Hoving et al. (2011) found that sows attain the best reproductive parameters between parity 3 and 5 .

Breed is very important factor affecting the reproductive performance of sows. Producers striving to increase productivity use not only pure breed but also crossbreed sows (Vanderhaeghe et al., 2010). The genetic potential of pigs has drastically changed over the last 50 years, affecting the improvement of production parameters (Brown-Brandt et al., 2004). The most severe pig selections have been made in nucleus herds from temperate climates in combination with improved environmental conditions (Knap, 2005). High performance is also achieved through the application of appropriate crossing programs on the maternal side (Bösch et al., 2000). The result is the effect of heterosis which effects an improvement of reproductive traits burdened with low heritability.

The aim of this study was to determine not only the simple effect of the season, the parity and breed on the selected reproductive performance parameters of sows, but primarily to investigate the interaction between the factors studied and an indication of the periods in which producers can expect decrease and increase in the number of live born and weaned piglets and also the periods in which piglets have lower and higher birth and weaned weight to ensure the uninterrupted stability and continuity of production.

\section{Material and methods}

\subsection{Experimental location and design}

The research was carried out on an industrial pig farm located in Opole province, Poland. The farm is located in a temperate climate zone, which is distinguished by the four seasons - climatic periods. On this basis, the sows were divided into the four experimental groups on the basis of farrowing time: Winter (January-March), Spring (April-June), Summer (July-September) and Autumn (October-December).

\subsection{Experimental animals, housing and feeding}

The experimental material consisted of 2100 sows, in 3 breed variants: 700 PL， 700 PLW， 700 crossbreeds PL $\times$ PLW. Sows were observed until parity 5 . In the context of the breed, depending on the order of parity groups of 140 sows were isolated. Then, sows were divided in terms of farrowing season into subgroups numbering 35 sows. At the age of 8 months gilts were allocated for reproduction performance.

After insemination, sows were housed for a period of one month in separate pens. Then, sows were kept in group pens (10 sows), with access to range. Sows were moved to the farrowing pens a week before the end of pregnancy. During the first period of pregnancy, sows were fed $2.80 \mathrm{~kg} \mathrm{day}^{-1}$, which consisted of $11.22 \mathrm{MJ}$ metabolic energy, $139.40 \mathrm{~g}$ crude protein, $6.30 \mathrm{~g}$ lysine, $5.25 \mathrm{~g}$ methionine + cystine, $8.85 \mathrm{~g} \mathrm{Ca}, 6.35 \mathrm{~g} \mathrm{P}$ and $2.75 \mathrm{~g} \mathrm{Na}$. After day 85 of pregnancy daily feed was increased to $3.25 \mathrm{~kg} \mathrm{day}^{-1}$, which consisted of $12.64 \mathrm{MJ}$ metabolic energy, $170.23 \mathrm{~g}$ crude protein, $10.23 \mathrm{~g}$ lysine, $6.75 \mathrm{~g}$ methionine + cystine, $8.87 \mathrm{~g} \mathrm{Ca}, 7.24 \mathrm{~g} \mathrm{P}$ and $2.90 \mathrm{~g}$ Na. During lactation, sows were fed ad libitum.

\subsection{Insemination}

Signs of heat were detected in the presence of a boar twice a day. Heat was diagnosed observing the occurrence of standing reflex tolerance when pressure was applied on the spine. Sows were inseminated with Duroc $\times$ Pietrain $[D \times P]$ boar's semen. Spermatozoa concentration in seminal doses was $3.5 \times 10^{9}$ in $100 \mathrm{~mL}$. Dilution of semen was made with a BTS boar semen extender (Version 13525/0100 Antibiotic free, Minitube International, Verona, USA). Sows were inseminated with fresh semen or semen stored at a temperature of $15^{\circ} \mathrm{C}$, but for no longer than $48 \mathrm{~h}$. Before insemination, insemination doses were heated to a temperature of $35^{\circ} \mathrm{C}$. Insemination was repeated after $24 \mathrm{~h}$. Pregnancy diagnosis was performed twice between 28 to 35 days after insemination using USG DRAMINSKI ${ }^{\circledR}$ SonoFarm profi (DRAMINSKI S.A, Olsztyn, Poland).

\subsection{Reproductive performance analysis}

The assessment of reproductive performance was carried out for each sow participating in the experiment. Four selected reproductive parameters were analysed: the number of live born piglets (head), the number of piglets weaned (head), average piglet birth weight $(\mathrm{kg})$ and average piglet weaned weight $(\mathrm{kg})$. The evaluation was performed on litters immediately after the completion of delivery and during the end of the lactation period. To assess the weight of the piglets electronic scales were used. Piglets were weaned from sows after 28 days. The age structure of the sows involved in the experiment was similar.

\subsection{Statistical analysis}

The numerical material was analysed using the STATISTICA PL program (StatSoft, Inc. Tulsa, OK, USA). The values in the tables are arithmetic means $(\bar{x})$, standard deviations (SD). The collected data were checked for normality with the Kolmogorov-Smirnov (K-S) test with Lilliefors correction. In addition, the Brown-Forsythe test (B-F) determined whether the distributions of the variables have the same variance. To determine the effect of season, parity and breed on selected reproductive performance parameters, the threeway analysis of variance (ANOVA) was used. An advanced mixed model using the GLM procedure was used and this performed an analysis of variance for factorial designs. The significance of differences was calculated on the basis of Tukey's test. The levels of significance of differences were 
Table 1. The impact of the season, parity, breed and interaction of these factors on selected reproductive performance parameters of sows.

\begin{tabular}{lcccc}
\hline Factor & \multicolumn{4}{c}{ Parameter } \\
\cline { 2 - 5 } & $\begin{array}{l}\text { The total number } \\
\text { of live born piglets }\end{array}$ & $\begin{array}{l}\text { The total number } \\
\text { of weaned piglets }\end{array}$ & $\begin{array}{c}\text { Average piglet } \\
\text { birth weight }\end{array}$ & $\begin{array}{c}\text { Average piglet } \\
\text { weaned weight }\end{array}$ \\
\hline Season $-\mathrm{a}$ & $*$ & $*$ & $*$ & $* *$ \\
Parity $-\mathrm{b}$ & $* *$ & $*$ & $* *$ & $* *$ \\
Breed $-\mathrm{c}$ & $*$ & $*$ & $* *$ & $* *$ \\
Season $\times$ Parity $-(\mathrm{ab})$ & $*$ & $\mathrm{~ns}$ & $*$ & $* *$ \\
Season $\times$ Breed $-(\mathrm{ac})$ & $\mathrm{ns}$ & $\mathrm{ns}$ & $*$ & $* *$ \\
Parity $\times$ Breed $-(\mathrm{bc})$ & $*$ & $\mathrm{~ns}$ & $*$ & $* *$ \\
Season $\times$ Parity $\times$ Breed $-(\mathrm{abc})$ & $\mathrm{ns}$ & $\mathrm{ns}$ & $* *$ & $*$ \\
\hline
\end{tabular}

ns: not significant, ${ }^{*}$ statistically significant differences, with $0.01<P \leq 0.05,{ }^{* *}$ statistically highly significant differences, with $P \leq 0.01$.

given conventionally: significant $0.01<P \leq 0.05$ and highly significant $P \leq 0.01$. The statistical model was as follows:

$Y=\mu+a+b+c+(a b)+(a c)+(b c)+(a b c)$

where $Y$ is the value of the dependent variable, $\mu$ is the general average, $a$ is the main effect of the season [Winter, Spring, Summer, Autumn], $b$ is the main effect of the parity [1 parity, 2 parity, 3 parity, 4 parity, 5 parity], $c$ is the main effect of the breed [PL, PLW, PL $\times$ PLW], $(a b)$ is the interaction effect of season and parity, $(a c)$ is the interaction effect of season and breed, $(b c)$ is the interaction effect of parity and breed, $(a b c)$ is the interaction effect of season, parity and breed.

\section{Results}

The statistical analysis confirmed the significant impact of three studied factors for all the evaluated parameters of sow reproductive performance (Table 1). The highest seasonal impact was noted for piglet birth weight $(P \leq 0.01)$. Parity had less effect only on the number of piglets weaned $(P \leq 0.05)$. Breed influenced to a lesser extent the number of piglets born live and weaned $(P \leq 0.05)$, while birth and weaning weight had greater importance for piglets $(P \leq$ $0.01)$.

The interaction between the studied factors was also observed. The impact of season, parity and breed interdependence on the number of piglets born live were confirmed statistically $(P \leq 0.05)$. Additionally, the existence was observed of four interactions on piglet birth and weaning weight. The analysis of piglet birth weight allowed the stronger interaction effect of parity $\times$ breed on this parameter to be noted $(P \leq 0.01)$. The analysis of variance for piglet weaning weight confirmed strong relations between all tested factors $(P \leq 0.01)$.

Detailed results of the effects of factors on the number of live born piglets are shown in Table 2. A significant decrease in the number of piglets for PL breed, in comparison with PLW breed and PL $\times$ PLW was recorded in parity
3 during Summer, and the fourth parity also during Summer $(P \leq 0.05)$. The largest differences between seasons for PL sows was noted in parities 3,4 , and $5(P \leq 0.05)$. The greatest number of live born piglets for PL sows was observed in parity 5 during Winter $(P \leq 0.05)$.

PLW sows bore the lowest number of piglets in parity 1 $(P \leq 0.05)$. A very low value of this parameter was also observed in parity 2 during Winter $(P \leq 0.05)$. A large variation in the number of live born piglets was listed for PLW sows between seasons in parities 2,3 , and $5(P \leq 0.05)$. The highest number of live born piglets was reported in parity 3 during Winter $(P \leq 0.05)$.

Similar to PLW sows, PL $\times$ PLW crossbreed sows bore the smallest number of piglets in parity $1(P \leq 0.05)$. Crossbreeds achieve the highest number of live born piglets in parity 4 during Summer $(P \leq 0.05)$. In terms of the parity data there were no differences between seasons for crossbreed sows.

The results of the analysis of the effect of season, parity and breed on the number of piglets weaned are shown in Table 3. A considerable reduction in the number of piglets weaned for PL breed compared to other breeds was observed in parity 3 during Winter and Summer, and parity 4 during Summer $(P \leq 0.05)$, which has a direct relationship with the number of live born piglets during these periods. Significant differences between seasons for PL sows were noted in parities 1 and $5(P \leq 0.05)$. The highest number of piglets weaned from the sow was recorded in parity 5 during Autumn $(P \leq 0.05)$.

In the case of PLW sows the smallest number of piglets weaned were shown during parity $1(P \leq 0.05)$, which resulted from the very small number of live born piglets per litter in this parity. It should be noted that the lowest value of this parameter was also recorded in parity 2 during Winter $(P \leq 0.05)$. Significant differences in the number of piglets weaned were observed for these sows between seasons in parities 2,3 , and $4(P \leq 0.05)$. The highest number of piglets was weaned from PLW sows in parities 3 and 4 during the Summer $(P \leq 0.05)$. 
Table 2. The impact of season, parity and breed on the total number of live born piglets.

\begin{tabular}{|c|c|c|c|c|}
\hline \multicolumn{2}{|c|}{ Factor } & \multicolumn{3}{|c|}{ The total number of live born piglets (head) } \\
\hline Parity & Season & PL & PLW & {$[\mathrm{PL} \times \mathrm{PLW}]$} \\
\hline \multirow[t]{4}{*}{1} & Winter & $10.18^{\mathrm{f}} \pm 2.01$ & $9.80^{\mathrm{f}} \pm 2.54$ & $9.39^{\mathrm{f}} \pm 2.33$ \\
\hline & Spring & $10.11 \pm 2.60$ & $9.71^{\mathrm{f}} \pm 2.43$ & $9.86^{\mathrm{f}} \pm 2.26$ \\
\hline & Summer & $9.89 \pm 2.36$ & $10.08^{\mathrm{f}} \pm 2.66$ & $10.03^{\mathrm{f}} \pm 2.19$ \\
\hline & Autumn & $9.32^{\mathrm{f}} \pm 2.54$ & $9.46^{\mathrm{f}} \pm 2.58$ & $9.51^{\mathrm{f}} \pm 2.09$ \\
\hline \multirow[t]{4}{*}{2} & Winter & $10.17^{\mathrm{a}, \mathrm{f}} \pm 2.71$ & $9.17^{\mathrm{b}, \mathrm{d}, \mathrm{f}} \pm 2.47$ & $10.50^{\mathrm{a}, \mathrm{e}} \pm 1.95$ \\
\hline & Spring & $9.96^{\mathrm{f}} \pm 1.97$ & $10.57^{\mathrm{c}} \pm 2.50$ & $10.64 \pm 2.42$ \\
\hline & Summer & $10.62 \pm 2.26$ & $10.50^{\mathrm{c}} \pm 2.51$ & $10.66 \pm 1.81$ \\
\hline & Autumn & $10.00 \pm 2.75$ & $9.85 \pm 1.98$ & $10.21 \pm 2.91$ \\
\hline \multirow[t]{4}{*}{3} & Winter & $10.60^{\mathrm{b}, \mathrm{f}} \pm 2.14$ & $11.75^{\mathrm{a}, \mathrm{c}, \mathrm{e}} \pm 2.06$ & $10.98^{\mathrm{e}} \pm 2.02$ \\
\hline & Spring & $10.80^{c} \pm 2.61$ & $11.00^{\mathrm{e}} \pm 2.37$ & $10.81^{\mathrm{e}} \pm 2.30$ \\
\hline & Summer & $9.88^{\mathrm{b}, \mathrm{d}} \pm 2.16$ & $11.00^{\mathrm{a}, \mathrm{e}} \pm 2.67$ & $10.50 \pm 2.76$ \\
\hline & Autumn & $10.46^{\mathrm{e}} \pm 2.04$ & $10.38^{\mathrm{d}, \mathrm{e}} \pm 2.57$ & $10.63^{\mathrm{e}} \pm 2.40$ \\
\hline \multirow[t]{4}{*}{4} & Winter & $10.46^{\mathrm{f}} \pm 2.63$ & $10.84^{\mathrm{e}} \pm 1.89$ & $10.33^{\mathrm{e}} \pm 2.66$ \\
\hline & Spring & $11.00^{\mathrm{c}, \mathrm{e}} \pm 2.55$ & $11.16^{\mathrm{e}} \pm 2.26$ & $10.49 \pm 2.69$ \\
\hline & Summer & $9.90^{\mathrm{b}, \mathrm{d}} \pm 2.19$ & $11.45^{\mathrm{a}, \mathrm{e}} \pm 2.57$ & $11.10^{\mathrm{a}, \mathrm{e}} \pm 1.87$ \\
\hline & Autumn & $10.44^{\mathrm{e}} \pm 2.23$ & $10.57^{\mathrm{e}} \pm 1.82$ & $10.21 \pm 1.81$ \\
\hline \multirow[t]{4}{*}{5} & Winter & $11.56^{\mathrm{a}, \mathrm{c}, \mathrm{e}} \pm 2.42$ & $11.00^{\mathrm{a}, \mathrm{c}, \mathrm{e}} \pm 1.90$ & $10.07^{b} \pm 2.65$ \\
\hline & Spring & $10.22^{\mathrm{d}} \pm 1.78$ & $10.00^{\mathrm{d}, \mathrm{f}} \pm 2.42$ & $10.56 \pm 2.31$ \\
\hline & Summer & $10.26^{\mathrm{d}} \pm 2.58$ & $10.55 \pm 1.86$ & $10.11^{\mathrm{f}} \pm 2.75$ \\
\hline & Autumn & $10.63^{\mathrm{d}, \mathrm{e}} \pm 2.68$ & $10.00^{\mathrm{d}} \pm 2.36$ & $10.48^{\mathrm{e}} \pm 1.76$ \\
\hline
\end{tabular}

\footnotetext{
a,b In the same row signifies statistically significant differences between breeds, with $P<0.05, \mathrm{c}, \mathrm{d}$ in the same column signifies statistically significant differences between seasons for the specific breed within the same parity, with $P<0.05$, e,f in the same column signifies statistically significant differences between parities for the specific breed within the same seasons, with $P<0.05$.
}

Crossbreed PL $\times$ PLW sows weaned the lowest number of piglets in parity 1 , especially during Winter $(P \leq 0.05)$. The highest number of piglets weaned was achieved in parity 4 during Summer $(P \leq 0.05)$. Differences in the number of piglets weaned were noted between seasons in parities 1 and 4 for PL $\times$ PLW sows $(P \leq 0.05)$.

Table 4 shows the influence of the examined factors on the birth weight of piglets. It can be noted that piglets born by PL and PLW were characterized by a lower birth weight compared to piglets born by PL $\times$ PLW crossbreeds $(P \leq 0.05)$. Lower birth weights of piglets born in parity 1 were observed for all the studied breeds $(P \leq 0.05)$. Large differences between seasons were noted for PL breed in parities 3, 4 and $5(P \leq 0.05)$. However, for PLW sows differences between seasons were recorded in parities 2,3 and 5 ( $P \leq$ 0.05). Significant fluctuations in birth weights of piglets were confirmed statistically between seasons only in parity 5 for PL $\times$ PLW crossbreed sows $(P \leq 0.05)$.

Sows of PL breed bore the highest number of piglets in parities 3 and 4 during Summer $(P \leq 0.05)$. The highest birth weight for PLW sows were observed in parity 3 during Autumn $(P \leq 0.05)$, while for crossbreeds PL $\times$ PLW in parity 4 during Summer and Autumn $(P \leq 0.05)$.
Table 5 presents the effect of the analysed factors on weaning weights of piglets. It should be noted that piglets weaned from purebred sows PL, PLW were lighter than piglets weaned from crossbreed sows PL $\times$ PLW $(P \leq 0.05)$. The lowest weaned weights were observed in parity $1(P \leq 0.05)$. Significant fluctuations between seasons were observed for PL sows in all parities $(P \leq 0.05)$. Changes in the weaning weight of piglets between seasons for PLW sows were observed in parities 1,3 and 4 ( $P \leq 0.05)$. Only in parity 1 were differences in the weaning weight of piglets for PL $\times$ PLW sows within seasons were not confirmed statistically.

The highest numbers of piglets for PL sows were weaned in parity 3 during Summer $(P \leq 0.05)$. The highest weaning weights for PLW breed were achieved in parity 3 during Autumn $(P \leq 0.05)$, while for crossbreed sows PL $\times$ PLW also in parity 3 during Autumn $(P \leq 0.05)$.

\section{Discussion}

The results of our study indicate differing (equivocal) impacts of the studied factors on the reproductive performance of sows. Its effect on the reproductive parameters occurs regardless of the reproductive management level in a herd ( $\mathrm{Au}-$ 
Table 3. The impact of season, parity and breed on the total number of weaned piglets.

\begin{tabular}{lllll}
\hline \multicolumn{2}{c}{ Factor } & \multicolumn{3}{c}{ The total number of weaned piglets (head) } \\
\hline Parity & Season & PL & PLW & {$[$ PL $\times$ PLW $]$} \\
\hline 1 & Winter & $9.71 \pm 1.99$ & $9.50^{\mathrm{f}} \pm 1.27$ & $9.03^{\mathrm{d}, \mathrm{f}} \pm 1.11$ \\
& Spring & $10.00^{\mathrm{c}} \pm 1.60$ & $9.62^{\mathrm{f}} \pm 1.34$ & $9.75 \pm 1.27$ \\
& Summer & $9.78 \pm 1.20$ & $9.92^{\mathrm{f}} \pm 1.67$ & $9.91^{\mathrm{c}} \pm 1.02$ \\
& Autumn & $9.04^{\mathrm{d}, \mathrm{f}} \pm 1.40$ & $9.29 \pm 1.52$ & $9.20 \pm 1.93$ \\
\hline 2 & Winter & $10.00^{\mathrm{a}} \pm 1.60$ & $9.00^{\mathrm{b}, \mathrm{d}, \mathrm{f}} \pm 1.26$ & $9.75 \pm 1.24$ \\
& Spring & $9.42^{\mathrm{f}} \pm 1.25$ & $10.00^{\mathrm{c}} \pm 1.86$ & $10.10 \pm 1.94$ \\
& Summer & $10.15 \pm 1.90$ & $10.00^{\mathrm{c}, \mathrm{f}} \pm 1.10$ & $9.86 \pm 1.27$ \\
& Autumn & $9.75 \pm 1.71$ & $9.70 \pm 1.98$ & $9.74 \pm 1.90$ \\
\hline 3 & Winter & $9.80^{\mathrm{b}} \pm 1.45$ & $10.75^{\mathrm{a}, \mathrm{c}, \mathrm{e}} \pm 1.50$ & $10.14^{\mathrm{e}} \pm 1.64$ \\
& Spring & $10.30^{\mathrm{e}} \pm 1.06$ & $10.21 \pm 1.63$ & $10.11 \pm 1.97$ \\
& Summer & $9.76^{\mathrm{b}} \pm 1.03$ & $10.88^{\mathrm{a}, \mathrm{c}, \mathrm{e}} \pm 1.12$ & $10.06 \pm 1.39$ \\
& Autumn & $9.92^{\mathrm{e}} \pm 1.30$ & $9.85^{\mathrm{d}} \pm 1.16$ & $9.89 \pm 1.98$ \\
\hline 4 & Winter & $9.73 \pm 1.15$ & $10.52^{\mathrm{a}, \mathrm{e}} \pm 1.02$ & $9.57^{\mathrm{b}, \mathrm{d}} \pm 1.14$ \\
& Spring & $10.40^{\mathrm{e}} \pm 1.83$ & $10.50^{\mathrm{e}} \pm 1.09$ & $10.02 \pm 1.32$ \\
& Summer & $9.70^{\mathrm{b}} \pm 1.95$ & $10.90^{\mathrm{a}, \mathrm{c}, \mathrm{e}} \pm 1.12$ & $10.58^{\mathrm{a}, \mathrm{c}, \mathrm{e}} \pm 1.40$ \\
& Autumn & $9.95^{\mathrm{e}} \pm 1.93$ & $9.79^{\mathrm{d}} \pm 1.25$ & $9.57^{\mathrm{d}} \pm 1.07$ \\
\hline 5 & Winter & $10.33^{\mathrm{a}} \pm 1.50$ & $9.64^{\mathrm{f}} \pm 1.96$ & $9.40^{\mathrm{b}} \pm 1.04$ \\
& Spring & $9.56^{\mathrm{d}} \pm 1.24$ & $9.44^{\mathrm{f}} \pm 1.42$ & $9.92 \pm 1.63$ \\
& Summer & $9.68 \pm 1.12$ & $9.79^{\mathrm{f}} \pm 1.24$ & $9.47^{\mathrm{f}} \pm 1.27$ \\
& Autumn & $10.44^{\mathrm{c}, \mathrm{e}} \pm 1.51$ & $9.75 \pm 1.20$ & $9.61 \pm 1.31$ \\
\hline
\end{tabular}

\footnotetext{
a,b In the same row signifies statistically significant differences between breeds, with $P<0.05,{ }^{\mathrm{c}, \mathrm{d}}$ in the same column signifies statistically significant differences between seasons for the specific breed within the same parity, with $P<0.05$, e,f in the same column signifies statistically significant differences between parities for the specific breed within the same seasons, with $P<0.05$.
}

vigne et al., 2010) and a far greater impact is created by genetic potential, environmental factors and climate (Hoving et al., 2011). In our study the lowest number of litters were born during Autumn; however, this effected the highest birth weight and associated with it weaning weight. The observed results might be explained by increased space in the female genital tract during foetal development, the relevant conditions during lactation and positive relationships between litter size and birth weight (Lund et al., 2002). Litter size and birth weight are conditioned by ovulation rate, embryonic survival and uterine capacity (Tummaruk et al., 2001). The reduction of piglets during rearing is mainly affected by factors dependent on sows, such as litter size and parity number (Weber et al., 2009). Therefore it is also confirmed by the none interaction effect of all analysed factors. Pére and Etienne (2000) demonstrated that uterine blood flow is increased to a lesser extent than the number of foetuses and a lower flow may result in less nutrition for foetuses. Additionally, Bérard et al. (2008) confirmed that weaning weight is directly proportional to birth weight. A significant effect of piglets birth weight on the growth rates showed in their studies Škorjanc et al. (2007). In contrast to the study conducted by Quesnel et al. (2008) there was no observed higher birth weight for piglets born in Spring. Maximum weight is in fact limited by the morphology and physiology of the sow.

Lower weaned weights in Summer were probably a result of microclimate conditions affecting lactation. Pigs are sensitive to high temperatures, mainly because of the reduced ability for perspiration (Nardone et al., 2010). It is very important to observe a body condition of sows during late pregnancy because of the later litter performance (Beyga and Rekiel, 2010). Physiological changes during farrowing and lactation are compounded by a change in diet, postnatal stress and microclimatic factors (Quesnel et al., 2009). Therefore, additional heat stress during Summer may have contributed to changes in the composition of milk, less milk secretion or decreased food consumption by piglets. On the other hand, heat stress may also impair the development of embryos and shape the reproductive performance of sows (Nardone et al., 2010), although our results recorded in Summer do not confirm such relationships.

Changes in reproductive parameters are also observed in the case of boars (Kawęcka et al., 2008). The effects of photoperiod on semen volume and total number of motile spermatozoa have been reported (Knecht et al., 2013). Our earlier studies presented changes in the total number of piglets born 
Table 4. The impact of season, parity and breed on average piglet birth weight.

\begin{tabular}{lllll}
\hline \multicolumn{2}{c}{ Factor } & \multicolumn{3}{c}{ Average piglet birth weight $(\mathrm{kg} / \mathrm{head})$} \\
\hline Parity & Season & PL & PLW & {$[\mathrm{PL} \times$ PLW $]$} \\
\hline 1 & Winter & $1.33^{\mathrm{b}, \mathrm{f}} \pm 0.23$ & $1.34^{\mathrm{b}, \mathrm{f}} \pm 0.18$ & $1.45^{\mathrm{a}, \mathrm{f}} \pm 0.25$ \\
& Spring & $1.34^{\mathrm{f}} \pm 0.18$ & $1.35^{\mathrm{f}} \pm 0.26$ & $1.41^{\mathrm{f}} \pm 0.22$ \\
& Summer & $1.36^{\mathrm{f}} \pm 0.20$ & $1.33^{\mathrm{f}} \pm 0.22$ & $1.36^{\mathrm{f}} \pm 0.24$ \\
& Autumn & $1.39^{\mathrm{f}} \pm 0.17$ & $1.38^{\mathrm{f}} \pm 0.16$ & $1.42^{\mathrm{f}} \pm 0.15$ \\
\hline 2 & Winter & $1.42^{\mathrm{b}} \pm 0.18$ & $1.51^{\mathrm{c}, \mathrm{e}} \pm 0.18$ & $1.53^{\mathrm{a}} \pm 0.23$ \\
& Spring & $1.47^{\mathrm{e}} \pm 0.18$ & $1.40^{\mathrm{b}, \mathrm{d}} \pm 0.21$ & $1.50^{\mathrm{a}} \pm 0.24$ \\
& Summer & $1.40^{\mathrm{b}, \mathrm{f}} \pm 0.25$ & $1.41^{\mathrm{b}, \mathrm{d}} \pm 0.16$ & $1.51^{\mathrm{a}, \mathrm{e}} \pm 0.26$ \\
& Autumn & $1.46 \pm 0.26$ & $1.45^{\mathrm{b}} \pm 0.20$ & $1.55^{\mathrm{a}, \mathrm{e}} \pm 0.22$ \\
\hline 3 & Winter & $1.49^{\mathrm{e}} \pm 0.20$ & $1.42^{\mathrm{b}, \mathrm{d}} \pm 0.16$ & $1.55^{\mathrm{a}, \mathrm{e}} \pm 0.16$ \\
& Spring & $1.46^{\mathrm{b}, \mathrm{d}, \mathrm{e}} \pm 0.17$ & $1.48^{\mathrm{e}} \pm 0.17$ & $1.56^{\mathrm{a}, \mathrm{e}} \pm 0.21$ \\
& Summer & $1.56^{\mathrm{c}, \mathrm{e}} \pm 0.21$ & $1.49^{\mathrm{b}, \mathrm{e}} \pm 0.24$ & $1.59^{\mathrm{a}, \mathrm{e}} \pm 0.24$ \\
& Autumn & $1.52^{\mathrm{e}} \pm 0.17$ & $1.54^{\mathrm{c}, \mathrm{e}} \pm 0.25$ & $1.57^{\mathrm{e}} \pm 0.18$ \\
\hline 4 & Winter & $1.51^{\mathrm{e}} \pm 0.17$ & $1.50^{\mathrm{e}} \pm 0.20$ & $1.58^{\mathrm{e}} \pm 0.22$ \\
& Spring & $1.48^{\mathrm{d}, \mathrm{e}} \pm 0.20$ & $1.48^{\mathrm{e}} \pm 0.22$ & $1.55^{\mathrm{e}} \pm 0.23$ \\
& Summer & $1.58^{\mathrm{a}, \mathrm{c}, \mathrm{e}} \pm 0.22$ & $1.47^{\mathrm{b}, \mathrm{e}} \pm 0.18$ & $1.60^{\mathrm{a}, \mathrm{e}} \pm 0.26$ \\
& Autumn & $1.51^{\mathrm{e}} \pm 0.19$ & $1.52^{\mathrm{e}} \pm 0.15$ & $1.60^{\mathrm{e}} \pm 0.21$ \\
\hline 5 & Winter & $1.35^{\mathrm{b}, \mathrm{d}, \mathrm{f}} \pm 0.25$ & $1.39^{\mathrm{b}, \mathrm{d}, \mathrm{f}} \pm 0.22$ & $1.51^{\mathrm{a}} \pm 0.18$ \\
& Spring & $1.47^{\mathrm{c}, \mathrm{e}} \pm 0.20$ & $1.49^{\mathrm{c}, \mathrm{e}} \pm 0.24$ & $1.45^{\mathrm{d}, \mathrm{f}} \pm 0.20$ \\
& Summer & $1.45^{\mathrm{b}, \mathrm{c}, \mathrm{f}} \pm 0.21$ & $1.45^{\mathrm{b}, \mathrm{e}} \pm 0.26$ & $1.55^{\mathrm{a}, \mathrm{c}, \mathrm{e}} \pm 0.23$ \\
& Autumn & $1.43^{\mathrm{c}} \pm 0.16$ & $1.50^{\mathrm{c}, \mathrm{e}} \pm 0.17$ & $1.45^{\mathrm{d}, \mathrm{f}} \pm 0.27$ \\
& & &
\end{tabular}

a,b In the same row signifies statistically significant differences between breeds, with $P<0.05, \mathrm{c}, \mathrm{d}$ in the same column signifies statistically significant differences between seasons for the specific breed within the same parity, with $P<0.05$, e,f in the same column signifies statistically significant differences between parities for the specific breed within the same seasons, with $P<0.05$.

and birth weight of piglets according to boar birth season (Knecht et al., 2014). It should be noted, however, that these studies concerned collected ejaculate. In our present experiment, all sows were inseminated with sperm doses containing an identical spermatozoa concentration, which eliminated the effect on the measured parameters of seasonal changes in boar semen.

One of the factors was also the parity. The observations already made by Scholman and Dijkhuizen (1989) had shown that it was economically viable to keep sows at least until parity 5 . Therefore, in our methodology we adopted just such a scope of parities. In the early 1990s it had been proved that a low degree of culling and basing production on sows with a large number of litters is the most profitable, because young gilts/sows are most vulnerable to various types of dysfunctions (Faust et al., 1993).

The farrowing results of the first parity may decide on parameters of further condition (Hoving et al., 2011). Engblom et al. (2007) even show that with the increase of parity, there is an increase in the number of live born and weaned piglets, because the correlation between these parameters is high. Such observations confirmed Čechová and Tvrdoň (2006) and it is strictly correlated with backfat thickness. Our re- sults confirm the influence of parity on the number of live born piglets. Quesnel et al. (2008) found that, sows in the 1st and 2 nd parities showed the most homogeneous litters. This may be due to the lower number of piglets born and therefore the increased space for foetal development in the uterus. We obtained the best results in parity 3 where a production peak was observed, then parameters began to fall slowly at paritiy 4 and drastically at 5 . However, in parity 5 all analysed parameters declined, and these were much better than the results of only parity 1 . This should be translate by the increased exploitation of the body and reproductive disorders.

There are differences between the breeds and their reactions to the examined factors. The improvements implemented in the direction of increased ovulation rates and greater embryonic survivals were made without a concomitant improvement of the uterine capacity (Foxcroft, 2007). Crossbreed sows covered by the study showed a number of born and weaned piglets compared to purebred which was similar for PL and lower for PLW. This is in contrast to the observations of Quesnel et al. (2008), who compared LW breed and LW $\times$ L crossbreed always achieve higher number of live born piglets for crossbreeds. The birth and weaning weight of piglets from crossbreed sows was higher. How- 
Table 5. The impact of season, parity and breed on average piglet weaned weight.

\begin{tabular}{|c|c|c|c|c|}
\hline \multicolumn{2}{|c|}{ Factor } & \multicolumn{3}{|c|}{ Average piglet weaned weight (kg/head) } \\
\hline Parity & Season & PL & PLW & {$[\mathrm{PL} \times \mathrm{PLW}]$} \\
\hline \multirow[t]{4}{*}{1} & Winter & $8.30^{\mathrm{c}, \mathrm{f}} \pm 0.32$ & $8.26^{\mathrm{b}, \mathrm{f}} \pm 0.33$ & $8.39^{\mathrm{a}, \mathrm{f}} \pm 0.25$ \\
\hline & Spring & $8.14^{\mathrm{b}, \mathrm{d}, \mathrm{f}} \pm 0.35$ & $8.20^{\mathrm{b}, \mathrm{d}, \mathrm{f}} \pm 0.35$ & $8.31^{\mathrm{a}, \mathrm{f}} \pm 0.35$ \\
\hline & Summer & $8.30^{\mathrm{a}, \mathrm{c}, \mathrm{f}} \pm 0.30$ & $8.17^{\mathrm{b}, \mathrm{d}, \mathrm{f}} \pm 0.37$ & $8.35^{\mathrm{a}, \mathrm{f}} \pm 0.30$ \\
\hline & Autumn & $8.31^{\mathrm{c}, \mathrm{f}} \pm 0.26$ & $8.34^{\mathrm{c}, \mathrm{f}} \pm 0.38$ & $8.36^{\mathrm{f}} \pm 0.37$ \\
\hline \multirow[t]{4}{*}{2} & Winter & $8.33^{\mathrm{b}, \mathrm{f}} \pm 0.38$ & $8.44^{\mathrm{a}, \mathrm{e}} \pm 0.32$ & $8.50^{\mathrm{a}, \mathrm{c}, \mathrm{e}} \pm 0.39$ \\
\hline & Spring & $8.42^{\mathrm{c}, \mathrm{e}} \pm 0.39$ & $8.37^{\mathrm{e}} \pm 0.35$ & $8.40^{\mathrm{d}} \pm 0.38$ \\
\hline & Summer & $8.30^{\mathrm{b}, \mathrm{d}, \mathrm{f}} \pm 0.35$ & $8.38^{\mathrm{e}} \pm 0.26$ & $8.44^{\mathrm{a}} \pm 0.35$ \\
\hline & Autumn & $8.37^{\mathrm{b}, \mathrm{f}} \pm 0.37$ & $8.40^{\mathrm{b}, \mathrm{f}} \pm 0.35$ & $8.51^{\mathrm{a}, \mathrm{c}, \mathrm{e}} \pm 0.34$ \\
\hline \multirow[t]{4}{*}{3} & Winter & $8.49^{\mathrm{a}, \mathrm{c}, \mathrm{e}} \pm 0.31$ & $8.35^{\mathrm{b}, \mathrm{d}} \pm 0.36$ & $8.48^{\mathrm{a}, \mathrm{d}} \pm 0.31$ \\
\hline & Spring & $8.36^{\mathrm{b}, \mathrm{d}, \mathrm{e}} \pm 0.37$ & $8.39^{\mathrm{b}, \mathrm{d}, \mathrm{e}} \pm 0.39$ & $8.49^{\mathrm{a}, \mathrm{d}, \mathrm{e}} \pm 0.34$ \\
\hline & Summer & $8.54^{\mathrm{a}, \mathrm{c}, \mathrm{e}} \pm 0.39$ & $8.31^{\mathrm{b}, \mathrm{d}, \mathrm{e}} \pm 0.31$ & $8.52^{\mathrm{a}, \mathrm{e}} \pm 0.27$ \\
\hline & Autumn & $8.50^{\mathrm{b}, \mathrm{c}, \mathrm{e}} \pm 0.27$ & $8.54^{\mathrm{c}, \mathrm{e}} \pm 0.35$ & $8.60^{\mathrm{a}, \mathrm{c}, \mathrm{e}} \pm 0.36$ \\
\hline \multirow[t]{4}{*}{4} & Winter & $8.46^{\mathrm{b}, \mathrm{e}} \pm 0.32$ & $8.40^{\mathrm{b}, \mathrm{e}} \pm 0.31$ & $8.57^{\mathrm{a}, \mathrm{c}, \mathrm{e}} \pm 0.32$ \\
\hline & Spring & $8.38^{\mathrm{b}, \mathrm{d}, \mathrm{e}} \pm 0.36$ & $8.41^{\mathrm{c}, \mathrm{e}} \pm 0.39$ & $8.49^{\mathrm{a}, \mathrm{e}} \pm 0.37$ \\
\hline & Summer & $8.50^{\mathrm{a}, \mathrm{c}, \mathrm{e}} \pm 0.32$ & $8.31^{\mathrm{b}, \mathrm{d}, \mathrm{e}} \pm 0.35$ & $8.40^{\mathrm{b}, \mathrm{d}, \mathrm{f}} \pm 0.31$ \\
\hline & Autumn & $8.39^{\mathrm{b}, \mathrm{d}, \mathrm{f}} \pm 0.34$ & $8.43^{\mathrm{b}, \mathrm{c}, \mathrm{f}} \pm 0.36$ & $8.58^{\mathrm{a}, \mathrm{c}, \mathrm{e}} \pm 0.35$ \\
\hline \multirow[t]{4}{*}{5} & Winter & $8.34^{\mathrm{b}, \mathrm{d}, \mathrm{f}} \pm 0.29$ & $8.40^{\mathrm{e}} \pm 0.38$ & $8.48^{\mathrm{a}, \mathrm{c}} \pm 0.37$ \\
\hline & Spring & $8.45^{\mathrm{a}, \mathrm{c}, \mathrm{e}} \pm 0.37$ & $8.43^{\mathrm{a}, \mathrm{e}} \pm 0.33$ & $8.32^{\mathrm{b}, \mathrm{d}, \mathrm{f}} \pm 0.33$ \\
\hline & Summer & $8.39^{f} \pm 0.35$ & $8.36^{\mathrm{e}} \pm 0.31$ & $8.41^{\mathrm{f}} \pm 0.35$ \\
\hline & Autumn & $8.30^{\mathrm{d}, \mathrm{f}} \pm 0.38$ & $8.39^{f} \pm 0.36$ & $8.38^{\mathrm{d}, \mathrm{f}} \pm 0.31$ \\
\hline
\end{tabular}

ever in our opinion, higher weaning weight was due to higher birth weight (Quesnel et al., 2008). In our results, no positive effect of crossbreeding on the number of piglets born live and weaned was noted. Improving reproductive performance is one of the reasons for the use of crossbreed sows (Vanderhaeghe et al., 2010). A higher number of live born piglets may reflect individual potential in the reproductive physiology of the breeds and crossbreeds in terms of not only high uterus capacity but also more resistance to environmental conditions such as climatic conditions, nutrition, etc. (Hoving et al., 2011). Bloemhof et al. (2008) reported that different lines respond differently to environmental factors and it is a possible genetic selection to heat stress tolerance. Selection in the direction of the number of piglets born also translated into the number of stillborn piglets, resulting in a small improvement in parameters of rearing (Rosendo et al., 2007). This follows from a positive correlation between litter size and the number of live born piglets (Quesnel et al., 2008).

In conclusion, the results have a very important practical character, because they show dynamic changes of reproductive performance parameters on an industrial piggery farm. The strength of the impact of season, parity and breed was very diverse. Season had the strongest effect on the weaning weight of piglets. Parity had less effect only on the number of piglets weaned. Breed most influenced piglet birth and weaned weight, especially for crossbreed sows [PL $\times$ PLW]. The study has shown the existence of interactions between the analysed factors for the number of piglets born live, birth and weaning weight. Research has shown that the worst reproductive parameters were noted in first parity. Gilts regardless of season and breed born the least alive piglets with the lowest birth weight, as well as weaned the smallest number of piglets with the very low weight. To ensure the uninterrupted stability and continuity of production, it is recommended to increase the number of PL, PLW and $[\mathrm{PL} \times \mathrm{PLW}]$ gilts in structure of technology groups. The best results in terms of the studied parameters were noted in sows with 3 and 4 parity. We observed that sows during this period born the largest number of alive piglets with a high weight and furthermore weaned greatest amount of piglets with higher weights. Increase in the average age of the sows in the herd improves the reproduction performance which results in higher piglets production. 
Acknowledgements. The authors wish to thank K. Bernhardt for revising the English version of the manuscript.

Edited by: K. Wimmers

Reviewed by: two anonymous referees

\section{References}

Auvigne, V., Leneveu, P., Jehannin, C., Peltoniemi, O., and Sallé, E.: Seasonal infertility in sows: A five year field study to analyze the relative roles of heat stress and photoperiod, Theriogenology, 74, 60-66, 2000.

Bérard, J., Kreuzer, M., and Bee, G.: Effect of litter size and birth weight on growth, carcass and pork quality, and their relationship to postmortem proteolysis, J. Anim. Sci., 86, 2357-2368, 2008.

Beyga, K. and Rekiel, A.: The effect of the body condition of the late pregnant sows on fat reserves at farrowing and weaning and on litter performance, Arch. Tierz., 53, 50-64, 2010.

Bloemhof, S., van der Waaij, E. H., Merks, J. W. M., and Knol, E. F.: Sow line differences in heat stress tolerance expressed in reproductive performance traits, J. Anim. Sci., 86, 3330-3337, 2008.

Bösch, M., Röhe, R., Looft, H., and Kalm, E.: Selection on purebred and crossbred performance for litter size in pigs, Arch. Tierz., 43, 249-262, 2000.

Brown-Brandt, T. M., Nienaber, J. A., Xin, H., and Gates, R. S.: A Literature Review of Swine Heat Production, T. ASAE, 47, 259-270, 2004.

Čechová, M. and Tvrdoň, Z.: Relationships between backfat thickness and parameters of reproduction in the Czech Large White sows (short communication), Arch. Tierz., 49, 363-369, 2006.

Engblom, L., Lundeheim, N., Dalin, A. M., and Andersson, K.: Sow removal in Swedish commercial herds, Livest. Sci., 106, 76-86, 2007.

Faust, M. A., Robison, O. W., and Tess, M. W.: Genetic and economic analyses of sow replacement rates in the commercial tier of a hierarchical swine breeding structure, J. Anim. Sci., 71, 1400-1406, 1993.

Foxcroft, G. R.: Pre-natal Programming of Variation in Post-Natal Performance - How and When?, Adv. Pork Prod., 18, 167-189, 2007.

Hoving, L. L., Soede, N. M., Graat, E. A. M., Feitsma, H., and Kemp, B.: Reproductive performance of second parity sows: Relations with subsequent reproduction, Livest. Sci., 140, 124-130, 2011.

Kawęcka, M., Pietruszka, A., Jacyno, E., Czarnecki, R., and Kamyczek, M.: Quality of semen of young boars of the breeds Pietrain and Duroc and their reciprocal crosses, Arch. Tierz., 51, 42-54, 2008.

Knap, P. W.: Breeding robust pigs, Aust. J. Exp. Agric., 45, 763773, 2005.

Knecht, D., Środoń, S., Szulc, K., and Duziński, K.: The effect of photoperiod on selected parameters of boar semen, Livest. Sci., $157,364-371,2013$.
Knecht, D., Środoń, S., and Duziński, K.: Does a Boar's Season of Birth Determine Semen Parameters and Reproductive Performance?, Reprod. Domest. Anim., 49, 183-190, 2014.

Love, R. J., Evans, G., and Klupiec, C.: Seasonal effects on fertility in gilts and sows, J. Reprod. Fertil. (Suppl.), 48, 191-206, 1993.

Lund, M. S., Puonti, M., Rydhmer, L., and Jensen, J.: Relationship between litter size and perinatal and pre-weaning survival in pigs, Anim. Sci., 74, 217-222, 2002.

Nardone, A., Ronchi, B., Lacetera, N., Ranieri, M. S., and Bernabucci, U.: Effects of climate changes on animal production and sustainability of livestock system, Lives.t Sci., 130, 57-69, 2010.

Patterson, J. L., Beltranena, E., and Foxcroft, G. R.: The effect of gilt age at first estrus and breeding on third estrus on sow body weight changes and long-term reproductive performance, J. Anim. Sci., 88, 2500-2513, 2010.

Père, M. C. and Etienne, M.: Uterine blood flow in sows: Effects of pregnancy stage and litter size, Reprod. Nutr. Dev., 40, 369-382, 2000.

Quesnel, H., Brossard, L., Valancogne, A., and Quiniou, N.: Influence of some sow characteristics on within-litter variation of piglet birth weight, Animal, 2, 1842-1849, 2008.

Quesnel, H., Meunier-Salaün, M. C., Hamard, A., Guillemet, R., Etienne, M., Farmer, C., Dourmad, J. Y., and Pére, M. C.: Dietary fiber for pregnant sows: Influence on sow physiology and performance during lactation, J. Anim. Sci., 87, 532-543, 2009.

Rosendo, A., Druet, T., Gogué, J., Canario, L., and Bidanel, J. P.: Correlated responses for litter traits to six generations of selection for ovulation rate or prenatal survival in French Large White pigs, J. Anim. Sci., 85, 1615-1624, 2007.

Scholman, G. J. and Dijkhuizen, A. A.: Determination and analysis of the economic optimum culling strategy in swine breeding herds in Western Europe and the USA, Neth. J. Agric. Sci., 37, 71-74, 1989.

Škorjanc, D., Brus, M., and Čandec Potokar, M.: Effect of Birth Weight and Sex on Pre-Weaning Growth Rate of Piglets, Arch. Tierz., 50, 476-486, 2007.

Takai, Y. and Koketsu, Y.: Number of services and the reservice intervals in relation to suboptimal reproductive performance in female pigs on commercial farms, Livest. Sci., 114, 42-47, 2008

Tummaruk, P., Lundeheim, N., Einarsson, S., and Dalin, A. M.: Effect of birth litter size, birth parity number, growth rate, backfat thickness and age at first mating of gilts on their reproductive performance as sows, Anim. Reprod. Sci., 66, 225-237, 2001.

Tummaruk, P., Tantasuparuk, W., Techakumphu, M., and Kunavongkrit, A.: Seasonal influences on the litter size at birth of pigs are more pronounced in the gilt than sow litters, J. Agric. Sci., 148, 421-432, 2010.

Vanderhaeghe, C., Dewulf, J., Ribbens, S., de Kruif, A., and Maes, D.: A cross-sectional study to collect risk factors associated with stillbirths in pig herds, Anim. Reprod. Sci., 118, 62-68, 2010.

Weber, R., Keil, N. M., Fehr, M., and Horat, R.: Factors affecting piglet mortality in loose farrowing systems on commercial farms, Livest. Sci., 124, 216-222, 2009.

Wysokińska, A. and Kondracki, S.: Assessment of the effect of heterosis on semen parameters of two-breed crosses of Duroc, Hampshire and Pietrain boars, Arch. Tierz., 56, 65-74, 2013. 